\title{
Trace Elements as Immunoregulators in SARS-CoV-2 and Other Viral Infections
}

\author{
Karthick Dharmalingam $^{1}$ - Amandeep Birdi ${ }^{1} \cdot$ Sojit Tomo $^{1} \cdot$ Karli Sreenivasulu $^{1}$ • \\ Jaykaran Charan $^{2} \cdot{\text { Dharmveer } \text { Yadav }^{1} \text { (D) Purvi Purohit }}^{1} \cdot$ Praveen Sharma $^{1}$
}

Received: 4 November 2020/Accepted: 23 January 2021/Published online: 12 February 2021

(C) The Author(s) 2021

\begin{abstract}
Nutritional deficiency is associated with impaired immunity and increased susceptibility to infections. The complex interactions of trace elements with the macromolecules trigger the effective immune response against the viral diseases. The outcome of various viral infections along with susceptibility is affected by trace elements such as zinc, selenium, iron, copper, etc. due to their immuno-modulatory effects. Available electronic databases have been comprehensively searched for articles published with full text available and with the key words "Trace elements", "COVID-19", "Viral Infections" and "Immune Response" (i.e. separately $\mathrm{Zn}, \mathrm{Se}, \mathrm{Fe}, \mathrm{Cu}, \mathrm{Mn}$, $\mathrm{Mo}, \mathrm{Cr}, \mathrm{Li}, \mathrm{Ni}, \mathrm{Co}$ ) appearing in the title and abstract. On the basis of available articles we have explored the role of trace elements in viral infections with special reference to COVID-19 and their interactions with the immune system. Zinc, selenium and other trace elements are vital to triggerT $_{\mathrm{H}} 1$ cells and cytokine-mediated immune response for substantial production of proinflammatory cytokines. The antiviral activity of some trace elements is attributed to their inhibitory effect on viral entry, replication and other downstream processes. Trace elements having antioxidants activity not only regulate host immune responses, but also modify the viral genome. Adequate dietary intake of trace elements is essential for activation, development, differentiation and numerous functions.
\end{abstract}

Dharmveer Yadav

dharam143s@gmail.com

1 Department of Biochemistry, All India Institute of Medical Sciences, Jodhpur, Rajasthan, India

2 Department of Pharmacology, All India Institute of Medical Sciences, Jodhpur, Rajasthan, India
Keywords Trace elements - Cell-mediated immunity · Zinc - Selenium - Copper · Manganese - Cytokines · Reactive oxygen species · COVID-19

\begin{tabular}{|c|c|}
\hline \\
\hline \multicolumn{2}{|l|}{$\begin{array}{l}\text { Abbreviations } \\
\text { ACE-2 }\end{array}$} \\
\hline cGAS & Cyclic GMP-AMP synthase \\
\hline CMI & Cell-mediated immunity \\
\hline COVID-19 & Coronavirus disease 2019 \\
\hline SARS-CoV-2 & $\begin{array}{l}\text { Severe acute respiratory syndrome } \\
\text { coronavirus- } 2\end{array}$ \\
\hline $\mathrm{Co}$ & Cobalt \\
\hline CQ & Chloroquine \\
\hline $\mathrm{Cr}$ & Chromium \\
\hline $\mathrm{Cu}$ & Copper \\
\hline ETC & Electron transport chain \\
\hline GPx & Glutathione peroxidase \\
\hline HCQ & Hydroxychloroquine \\
\hline HSV & Herpes simplex viruses \\
\hline IL & Interleukin \\
\hline $\mathrm{Li}$ & Lithium \\
\hline MERS & Middle East respiratory syndrome \\
\hline Mn & Manganese \\
\hline Mo & Molybdenum \\
\hline $\mathrm{n}-\mathrm{COV}$ & Novel coronavirus \\
\hline $\mathrm{Ni}$ & Nickel \\
\hline ROS & Reactive oxygen species \\
\hline SARS & Severe acute respiratory syndrome \\
\hline $\mathrm{Se}$ & Selenium \\
\hline SOD & Superoxide dismutase \\
\hline $\mathrm{Tc}$ & Cytotoxic T-cells \\
\hline TxR & Thioredoxin reductase \\
\hline $\mathrm{Zn}$ & Zinc \\
\hline
\end{tabular}




\section{Introduction}

Human being have witnessed three major epidemics caused by coronaviruses such as Severe Acute Respiratory Syndrome (SARS-2003), Middle East Respiratory Syndrome (MERS-2012) and novel Coronavirus (n-COV) Disease throughout the world in the recent past [1, 2]. COVID-19 was emerged in Wuhan city, China in December 2019. On 12th January 2020, World Health Organization (WHO) named it as novel coronavirus, and later on 11th February 2020 it was renamed as Severe Acute Respiratory Syndrome Coronavirus-2 (SARS-CoV-2) by WHO.

In order the curtail the spread of the SARS-CoV-2, any countries have implemented several measures like quarantine, wearing mask, social distancing and temporary closure of food-related companies and markets to avoid spread of the corona virus disease 2019 (COVID-19). During this period, individuals feel world-weariness and associated with consumption of higher quantities of macronutrients such as carbohydrates, fats and proteins [3]. The increased consumption of macronutrients could also be accompanied by deficiency of micronutrients. This imbalanced dietary habits are commonly associated with the impaired immune responses which leads to severe illnesses (Fig. 1), affecting both the innate and adaptive immunity, and makes people more susceptible to viral and other infections [4].

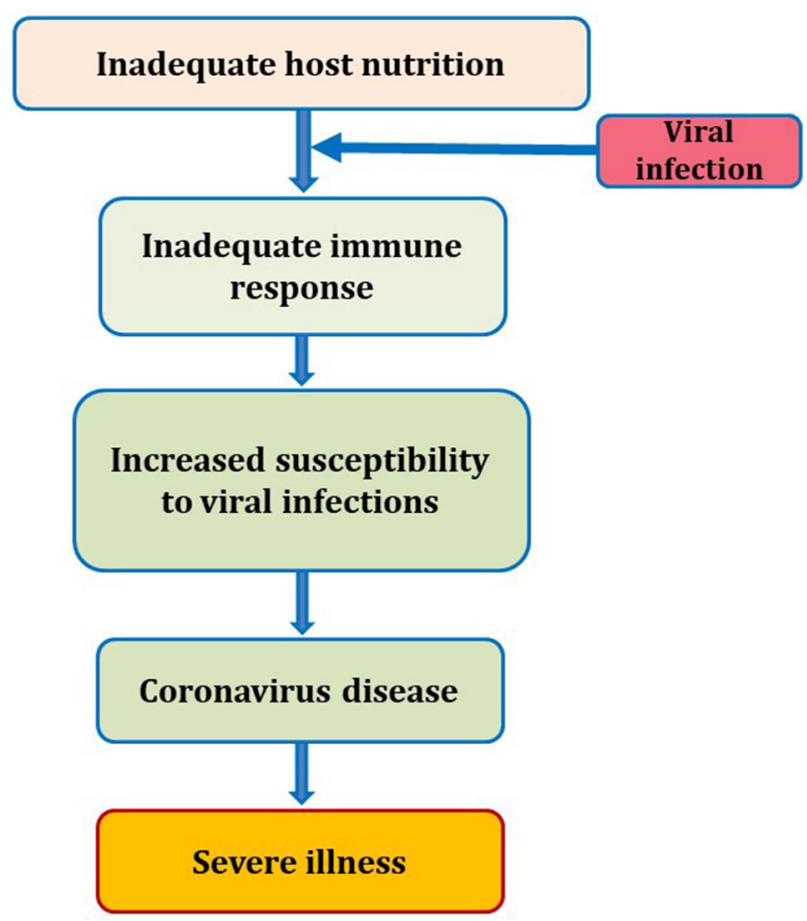

Fig. 1 Schematic representation of role of nutrition in immunity against viral infections
The maintenance of an adequate micronutrient balance might strengthen the host immune response and to be protective of viral infections [5]. Essential micronutrients such as selenium $(\mathrm{Se})$, zinc $(\mathrm{Zn})$, copper $(\mathrm{Cu})$, manganese $(\mathrm{Mn})$, etc. have immunomodulatory functions and thus influence the susceptibility to the course and the outcome of a variety of viral infections [6]. The trace elements, coronavirus and immune system interactions highlighted the importance of trace elements in nutrition of host to optimize immune response to infections, and in preventing viral mutations which could increase the viral pathogenicity. Available electronic databases including Pubmed, Google and Scopus have been comprehensively searched for articles published with full text available and with the key words "Trace elements", "COVID-19", "Viral Infections" and "Immune Response" (i.e. separately $\mathrm{Zn}, \mathrm{Se}, \mathrm{Fe}, \mathrm{Cu}, \mathrm{Mn}, \mathrm{Mo}, \mathrm{Cr}, \mathrm{Li}, \mathrm{Ni}, \mathrm{Co}$ ) appearing in the title and abstract. On the basis of available articles, we have explored the role of trace elements in viral infections with special reference to COVID-19 and their interactions with the immune system.

\section{Dietary Importance of Trace Elements}

Regular intake of trace elements gives immense significance to maintain general health. Recommended dietary allowance of various trace elements gives a clear structure for regular intake as a balanced diet to lead a healthy life [7] (Table 1). Intake of appropriate quantity is essential for performing the vital functions. Deficiency of trace elements results in sub-optimal functions, malnutrition, deficiency related diseases, while excess intake cause toxicity, which leads to fatal outcome (Fig. 2). Nutritional deficiency of trace elements are associated with impaired immunocompetence and increased susceptibility to infections [8].

There are eleven trace elements such as zinc, selenium, iron, copper, manganese, molybdenum, cobalt, iodide, fluoride, chromium and nickel. Evidences suggest that, vanadium, silicon and boron possess beneficial bioactivity in reasonable amounts [9]. Trace elements have proven to control the important cellular processes by binding to molecules on the receptor site of cell membrane or by alternating the structure of membrane to prevent entry of specific molecules into the cell [10]. Trace elements mediate vital biochemical functions by acting as cofactors for many enzymes such as glutathione peroxidise (GPx), superoxide dismutase (SOD), RNA polymerase, as well as act as centres for stabilizing structures of many enzymes and receptor proteins like Toll-like receptor-4 and transcription factors likeNf-kB [11, 12]. 
Table 1 Recommended dietary allowances of essential trace elements to promote immune functions

\begin{tabular}{llll}
\hline S. no & Trace elements & Supplementation quantity for adult male/day & Supplementation quantity for adult female/day \\
\hline 1 & Zinc & $11 \mathrm{mg}$ & $8 \mathrm{mg}$ \\
2 & Selenium & $55 \mu \mathrm{g}$ & $55 \mu \mathrm{g}$ \\
3 & Iron & $8 \mathrm{mg}$ & $18 \mathrm{mg}$ \\
4 & Copper & $900 \mu \mathrm{g}$ & $900 \mu \mathrm{g}$ \\
5 & Magnesium & $400 \mathrm{mg}$ & $310 \mathrm{mg}$ \\
\hline
\end{tabular}

Fig. 2 Potential adverse effects of trace elements in deficiency or overdose

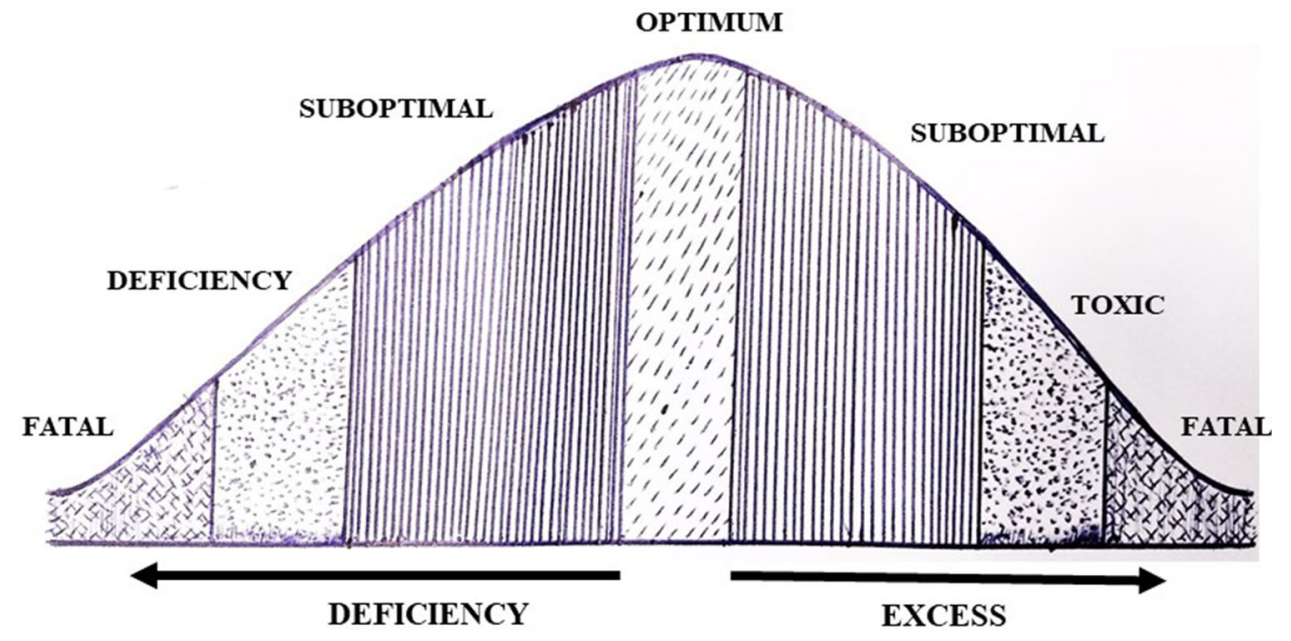

\section{Immunity Against Coronavirus Infections}

Coronaviruses are zoonotic viruses mainly responsible for respiratory illness. SARS-CoV-2 belongs to genus of $\beta$ coronavirus. Phylogenetic analysis of its whole genome confirms its similarity to SARS-CoV. Generally human immune system fights against viral infections through a variety of specific and non-specific mechanisms. Several immune defence mechanisms can eliminate viruses from the host. Antigen presenting cells like dendritic cells and macrophages phagocytose the antigens and break down into fragments with the help of lysosomes. These fragments are loaded onto major histocompatibility complexes class I or class II molecules, and are transported to the cell surface for antigen presentation. Toll-like receptors on $\mathrm{T}$ cells along with co-receptors binds to displayed antigen. Helper $\mathrm{T}$-cells secretes cytokines, which activates cytotoxic $\mathrm{T}\left(\mathrm{T}_{\mathrm{C}}\right)$ cells and $B$ cells. $T_{C}$ cells kills virus infected cells through cell-mediated immunity (CMI) and B cells secreted antibodies carry out humoral immunity [13]. Upon SARSCoV-2 infection releases enormous quantities of proinflammatory cytokines and chemokines by immune effector cells termed as 'cytokine storm'. The cytokine storm triggers a violent systemic inflammatory response, sepsis, multi-organ failure and finally death in severe cases. The immune evasion mechanism of coronavirus is mainly due to inhibition of Type-I interferon (IFN) production. Lack of type I IFN leads to defect in antibody production, effector T-cell response, expression of IFN stimulating genes and also decreased antigen presentation [14, 15].

\section{Trace Elements in Immune Response Against COVID-19 and Other Viral Infections}

\section{Zinc}

Zinc ( $\mathrm{Zn})$ is an integral component of zinc finger motifs and transcription factors. Approximately, 20\% of zinc is part of biomembrane proteins, $50 \%$ is present in cytosolic organelles and cytoplasm and $30 \%$ is found in nucleus [16]. An adequate concentration of $\mathrm{Zn}$ is essential for division, differentiation and maturation of T-lymphocytes, response of T-cells into mitogens, transcription of several immune regulatory genes in leukocytes. Severe $\mathrm{Zn}$ deficiency causes failure of both primary and secondary immune response. It is a component of $\mathrm{Zn}$ finger proteins, which act as transcription factors [17]. Zinc is essential for highly proliferating cells, especially in the immune system and influences both innate and acquired immune functions [18]. It is involved in the cytosolic defence against oxidative stress (SOD activity) and is an essential cofactor for 
thymulin, which modulates cytokine release and induces proliferation [19]. Zinc plays a pivotal role in central dogma and acts as cofactor in a number of enzymes, including RNA and DNA polymerases, ribonuclease and thymidine kinase. These enzymes are essential for immune cells growth, development, maturity and cell division (Fig. 3).

\section{Role of Zinc Against Oxidative Stress and SARS-CoV Infection}

Zinc is a divalent transition metal, key factor of antioxidant enzyme SOD. SOD converts superoxide $\left(\mathrm{O}_{2}{ }^{-}\right)$to hydrogen peroxide $\left(\mathrm{H}_{2} \mathrm{O}_{2}\right)$.

$\mathrm{O}_{2}^{--}+\mathrm{O}_{2}^{--}+2 \mathrm{H}^{+} \rightarrow \mathrm{H}_{2} \mathrm{O}_{2}+\mathrm{O}_{2}$

SARS-CoV-2 viral pathophysiological processes affect redox imbalance and oxidative stress. This phenomenon over produces the levels of reactive oxygen species (ROS) and deprived antioxidant defence mechanisms. A strong correlation between the oxidative stress markers and severity of viral diseases makes a crucial role for viral replication and its associated complications [20]. Several studies have suggested severe lung injury due to SARS$\mathrm{CoV}$ triggers oxidative stress coupled exacerbation of proinflammatory response through NF-kB, transcription factor. Zinc accomplished versatile functions involved in antioxidant system, regulate inflammatory response and improved antiviral mechanisms and possess protective adjuvant therapy for COVID-19. Dietary Zn supplements provide beneficial impacts on health and amelioration of the SARS-CoV-2 pandemic situations. Trace elements play a non-specific activator of antioxidant metalloenzymes on viral infections. Antioxidants increase the number of T-cell subsets, increased interleukin-2 production, enhance lymphocyte response to mitogens, potentiated natural killer cell activity and increased response to influenza virus vaccine compared with placebo [21].

\section{Role of Zinc in Immune System}

Several studies showed that depending on the type of stimulus and concentration of $\mathrm{Zn}$ the immune system can either be stimulated or suppressed. Adequate $\mathrm{Zn}$ intake supports a $\mathrm{T}_{\mathrm{H}} 1$ response, and helps to maintain mucosal membrane integrity, and unbound zinc ions exert a direct antiviral effect on rhinovirus replication. Zinc supplementation increases cellular components of innate immunity (e.g. phagocytosis by macrophages and neutrophils, NK cell activity, generation of oxidative burst, DTH activity), antibody responses and the numbers of cytotoxic $\mathrm{CD} 8^{+} \mathrm{T}$ cells $\left(\mathrm{T}_{\mathrm{H}} 1\right.$ response). Zinc deficiency results in lymphoid atrophy and decreased capacity to respond to many T-dependent antigens. High level of $\mathrm{Zn}$ is immunosuppressive, decreases the neutrophils and T-cell proliferation to mitogens and decrease antibody production. Thus, imbalance of $\mathrm{Zn}$ adversely affects immune functions [22]. Activity of thymic hormone decreases in deficiency of $\mathrm{Zn}, \mathrm{Cu}$ and $\mathrm{Se}$. Zinc deficiency of suboptimal levels in a mouse model reduced thymus size and depleted macrophages and lymphocytes in the spleen [23].

\section{Role of Zinc Against Coronavirus Pathogenesis}

Zinc is a booster of immune system and plays a vital role in immunocompetence [24]. It is involved in development and maturation of immune cells and inflammatory response. Zinc acts as cofactor of cellular machineries of replicative and transcriptional enzyme systems such as DNA and RNA polymerases, respectively. In hepatitis C and rhinovirus, $\mathrm{Zn}$ showed antiviral activity by inhibiting RNA dependent RNA polymerase (RdRp) and other
Fig. 3 Biochemical and antiviral functions of zinc

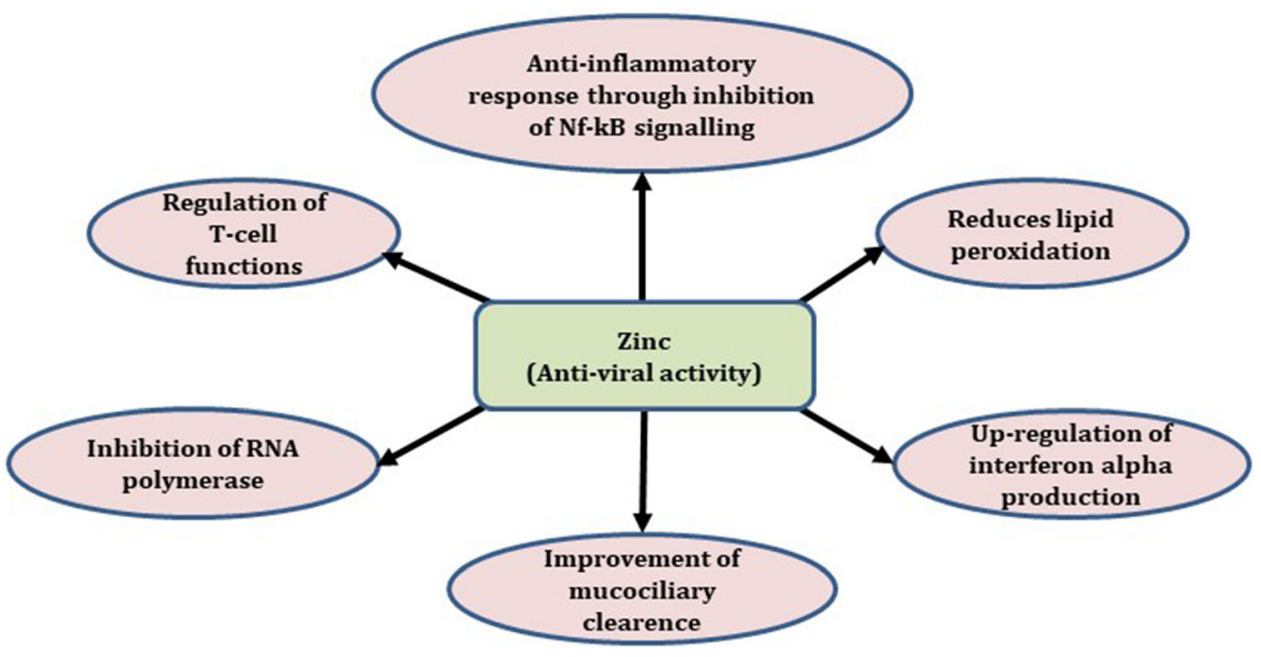


cellular cofactors [25]. Zinc inhibits the elongation phase of RNA synthesis in SARS-CoV, it might be due to effect on template binding. Proteolytic processing of replicase polyproteins and RdRp activity appears to be inhibited by zinc [26]. A distinctive feature of coronavirus replication is transcription of structural and accessory protein encoding genes in $5^{\prime}$ - and $3^{\prime}$-coterminal nidus set of subgenomic (sg) mRNAs [27]. In cell free systems and infected cells the processing of coronavirus replicase polyproteins are inhibited by $\mathrm{Zn}$ through hindering proteolytic mechanisms [28]. Studies based on several RNA viruses like picornaviruses, respiratory syncytial virus and influenza virus illustrated that, addition of compounds like pyrithione, hinokitol and pyrrolidinedithiocarbamate increases cellular Zn concentration, which inhibits replication [29]. The antiviral activity of chloroquine may be, attributed to its action as a $\mathrm{Zn}$ ionophore (Fig. 4).

Zinc is necessary for apoptosis. Transcription of genes belongs to lymphoid and myeloid origins [30]. Severe $\mathrm{Zn}$ deficiency individuals have decreased immune function. Supplementation of zinc along with chloroquine (CQ) or its metabolite hydroxychloroquine (HCQ) is more effective in reducing covid-19 morbidity and mortality than $\mathrm{CQ}$ and HCQ monotherapy [31]. Hydroxychloroquine inhibits antigen processing and presentation and stops the release of virus into the cytoplasm by decreases the acidity in endosomes [32]. Sattar et al. published a case report stated that intake of zinc along with azithromycin and chloroquine fastens the recovery rate in COVID-19 patients [33]. Studies carried in Vero-E6 cells have been reported that, zinc inhibits SARS-CoV RdRp through template binding and elongation. Synergistic actions of zinc and quercetin inhibits transcription of $\mathrm{RdRp}$ during transcription of SARS-CoV-1 genome [34]. The viral entry and reproductive cycle of SARS-CoV-2 was almost similar to SARS$\mathrm{CoV}$, whereas angiotensin-converting enzyme 2 (ACE-2) acts as receptors for SARS-CoV-2 entry into type-
IIpneumocytes [35]. Modulation of ACE-2 receptor levels by $\mathrm{Zn}$ treatment was considered as potential therapeutic strategy in COVID-19 treatment [36]. It was elucidated that exposure of $100 \mu \mathrm{M}$ concentration of $\mathrm{Zn}$ reduces recombinant human ACE-2 activity in rat lungs [37]. Zinc supplementation boosters the innate immunity through increase the interferon-alpha production by leucocytes [38]. Although the concentration is near to physiological level the modulating effect on SARS-CoV2-ACE-2 interaction seems to be only hypothetical. In SARS-CoV infection ciliary epithelia of respiratory mucosal membrane were severely damaged which leads to loss of mucous clearance, lower respiratory tract infections and pneumonia [39]. In animal model, treatment with zinc increases the length of cilia, mucous clearance, frequency of ciliary beat and integrity of ciliary epithelium [40-42].

\section{Selenium}

Selenium (Se) is essential for protein folding, calcium flux, activation, proliferation and differentiation of immune cells [43]. Selenium function in the form of selenoproteins/selenoenzymes like thioredoxin reductase (TxR) and GPx, plays a crucial role in redox regulations and antioxidant functions [44]. TrxR maintains the cellular pool of reduced thioredoxin. Reduced Trx is involved in regulation of DNA biosynthesis, activation of transcription factors and gene expressions in cell proliferation, apoptosis, migration and inflammatory pathways [45]. GPx is a cytosolic enzyme that requires reduced glutathione and hydrogen/lipid peroxides as substrates and converted into oxidized glutathione and water/oxygen as by products. Se promotes GPx and phospholipid levels in immune cells.

Selenium optimizes both innate and acquired immunity (Fig. 5). Low-dose supplementation of Se reduces humoral immunity against respiratory tract infections [46]. Selenium increases CMI through proliferation of $\mathrm{T}$ cells,
Fig. 4 Various mechanisms of Zinc's action against COVID19

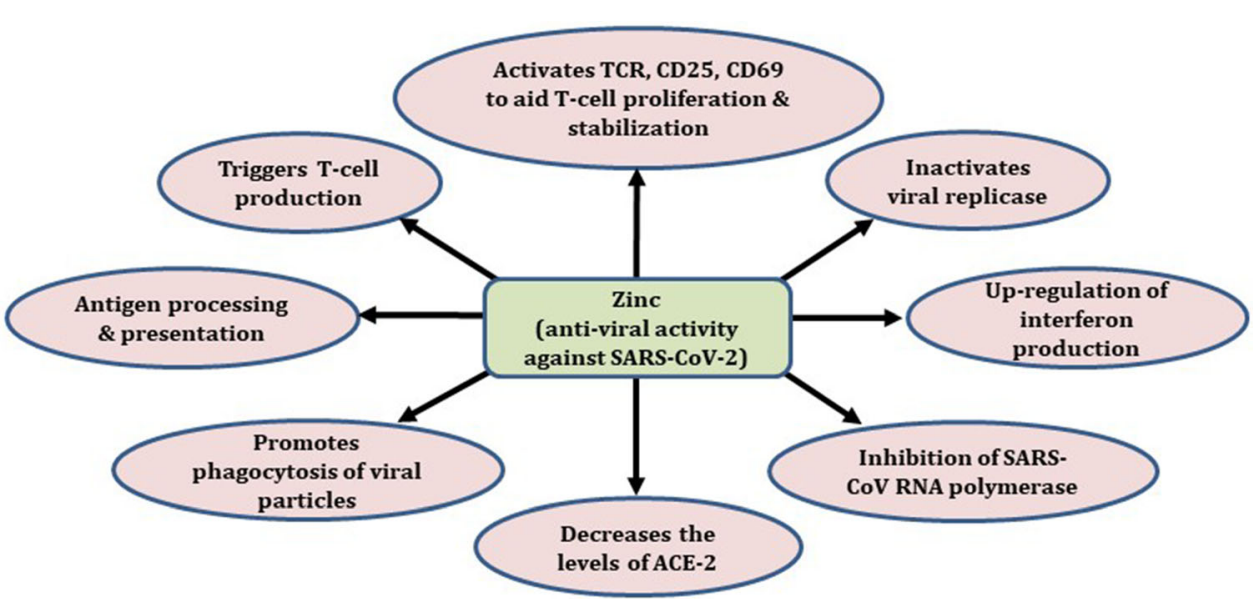


Fig. 5 Various mechanisms of biochemical and antiviral activities of selenium

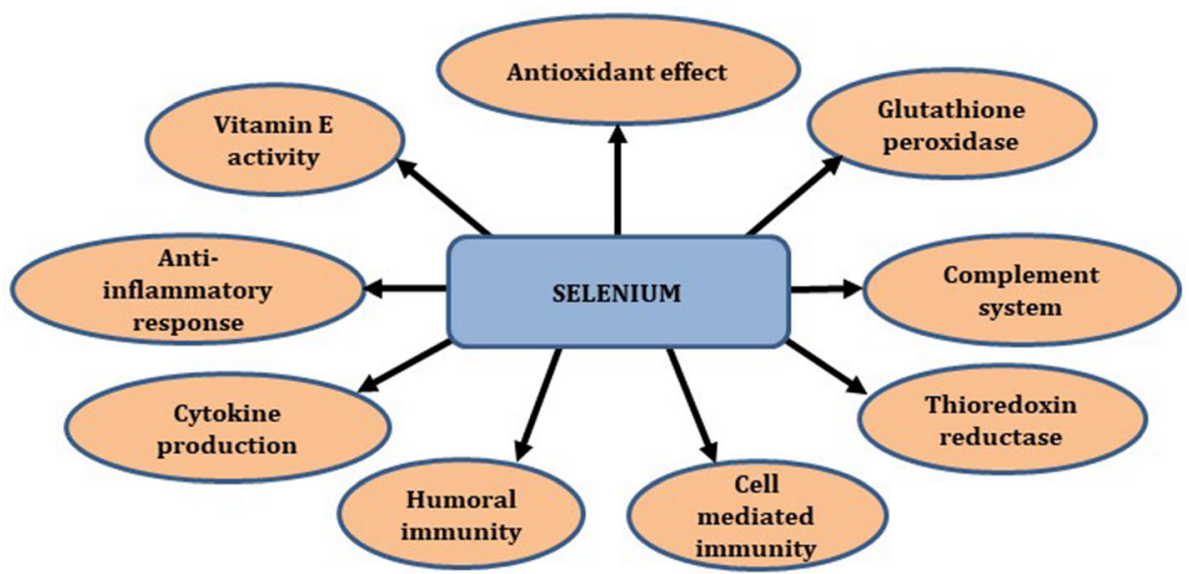

increased IFN- $\gamma$ and cytokines production. Selenium also promotes NK cell mediated immunity through perforingranzyme pathways [47]. Selenium deficiency has shown to reduce the immune system and favours pathogenicity of coronaviruses. It inhibits virus replication in the host cells. The virulence property of SARS-CoV is mainly depends on its penetration property into pneumocytes [48]. Sodium selenite stops the viral infectivity by preventing the entry of coronaviruses into healthy host cells [49]. Antiviral mechanism of selenite is exhibited through oxidize thiol groups in viral proteins and renders penetration into host cell membrane [50]. One study demonstrated that $\mathrm{Se}$ deficiency in Hubei province increased the virulence of SARS-CoV-2 pathogenicity [51]. Decreased serum Se concentration causes accumulation of mutations in the genome of HIV, influenza A and SARS coronavirus, indicating the changes in the virulence is associated genetic structures [52]. Several studies demonstrated in animal model showed selenium deficiency increases mutation of viral genome which leads to increased pathogenicity and mortality $[48,53]$.

Complement system is the part non-specific immune system where $\mathrm{ClqA}$ plays an important role. Influenza virus protein $\mathrm{M} 1$ interacts with $\mathrm{C} 1 \mathrm{qA}$ tightly, thereby escaping from the host immune systems [54]. Coronavirus has error-prone polymerase so that RNA can easily undergo several mutations and implicates the genetic diversity [55]. Selenium insufficiency causes oxidative damage to viral RNA and consequently increases the mutation rate. Increased mutation in viral genome favours the generation of pathogenic aggressive new strains. Selenium favours immuno-modulatory effects in many viral infections along with zinc. Adequate intake of nutrition showed better resilience and reduces the pathological conditions from COVID-19 infection [48]. In selenium deficient mice, several cytokines such as interleukin (IL)-4, IL-5, IL-10 and IL-13 were elevated, whereas IL-2 and IFN- $\gamma$ were decreased. This modification might changes the pattern of T-helper cell function which fetches increased virulence property of coronaviruses [40]. Selenium consort with vitamin $\mathrm{E}$, and prevent free radicals generation by assisting several types of enzymes. It prevents oxidative damage of immune cells and tissues. This synergistic effect induces immunity to a live bivalent infectious bronchitis coronavirus vaccine in chickens [56]. These observations suggested that intake of appropriate dose of Se may be effective therapeutic regimen for the treatment of SARS-CoV-2 infection.

\section{Iron}

Iron is vital for electron transport chain reaction. Oxygen binds to iron in hemoglobin and transported to different tissues. Differentiation of cells and cellular growth is also regulated by iron. Enzymes that generate peroxide and nitric oxide also have iron as structural component and cofactor [57]. Cytokine production and its mechanism of action required iron for regulation. Phosphorylation requires protein kinase $\mathrm{C}$ activation which is an important signalling molecule for immune cell proliferation that requires iron for activation [58]. Either iron deficiency or overload had unfavourable functional cost to the immune system. Continued existence and replication of contagious viruses and microorganisms have necessity of iron and other micronutrients. Only optimum concentration is required for the proper functioning of immune system against infectious agents. In iron deficient stage there is slight reduction in rosette forming $\mathrm{T}$ cells and impaired lymphocyte proliferation retort to mitogens and antigens [24].

Iron distribution has to be tightly controlled to decrease the admittance of potentially harmful microorganism to this trace element. Deficiency of iron leads to change in $\mathrm{T}$ lymphocyte numbers, particularly of the $\mathrm{CD}_{4}{ }^{+} \mathrm{T}_{\mathrm{H}} 1$ subpopulation [59]. Iron deficiency anemia in children is associated with the impaired maturation of $\mathrm{T}_{\mathrm{H}}$ cells and is 
revived by iron supplementation [60]. In comparison with $\mathrm{T}_{\mathrm{H}} 1$ lymphocytes, $\mathrm{T}_{\mathrm{H}} 2$ lymphocyte has larger and less labile iron stores. Thus effect of iron deficiency on $T_{H} 1$ lymphocytes is more as compared to $\mathrm{T}_{\mathrm{H}} 2$ cells. Iron deficiency leads to impairment of proliferation of lymphocytes are due to either reduced translocation or activation of protein kinase $\mathrm{C}$ [61].

Housekeeping processes like energy production as cytochromes a, b and c, NADH and succinate dehydrogenase require metalloproteins whose structure and functioning depends upon iron. Microbiocidal factor like myeloproxidase dependent generation of hypochlorous acid require haem iron [61]. Atrophy of thymus occurs in iron deficiency, not because of increase in programmed cell death [62]. Iron deficiency also leads to decrease in circulating $\mathrm{T}$ lymphocytes in blood. T-helper and $\mathrm{T}$-suppressor cells are very receptive to low iron levels.

Coronavirus replication requires sufficient amount of intracellular iron levels, whereas iron deficiency interferes in viral replication by impeding viral transcription, translation, assembly and exocytosis. Coronavirus enters the host cells by fusing its envelop with the host membrane and dismantle and release viral genome and nucleocapsid. Genomic RNA and structural proteins yield after transcription and translation. Coronavirus assembled in endoplasmic reticulum and Golgi apparatus after further processing and forms new progeny [63]. Finally, exocytosis of virion containing vesicles occurs. Iron containing enzymes and ATP is required during this process. Therefore, adequate amount of iron is required for coronavirus replication and iron deficiency make this process unfavourable [64-66].

\section{Copper}

Copper $(\mathrm{Cu})$ plays a vital role in the energy production through electron transport chain (ETC). Enzymes required copper for ETC are cytochrome $\mathrm{C}$ reductase and cytochrome oxidase. Certain enzymes like SOD require copper for its regulation and catalytic functions as enzymic antioxidant. Along with $\mathrm{Cu}, \mathrm{Zn}$ is also necessary for the action of SOD $(\mathrm{Cu}, \mathrm{Zn}-\mathrm{SOD})$, which can quench ROS. Copper plays a vital role by converting superoxide anions to oxygen and $\mathrm{H}_{2} \mathrm{O}_{2}$. Its deficiency can be diminished by dietary intake. It is also required for iron metabolism [67]. Copper in both excess and deficient condition alter the immune response. It plays a crucial role in the development, maturation and proper functioning of immune system. Copper deficiency causes decreased antibody forming cell response and increased susceptibility to a variety of viral infections [68]. Decreased number of circulating neutrophils known as 'neutropenia' is seen in Cu deficiency [69]. Severe $\mathrm{Cu}$ deficient rats exhibited reduced cellular $\mathrm{Cu}$ status, increased ROS and fungicidal activity on Candida albicans of peritoneal macrophages. Effectiveness of the acquired immune response is decreased in $\mathrm{Cu}$ deficiency. Copper deficient animals showed a decrease antibody production from spleen B cells [70]. Immunoglobulins and phagocytosis are comparatively low in $\mathrm{Cu}$-deficient children. There is significant improvement in phagocytic index after $\mathrm{Cu}$ supplementation in those children. Proliferation of peripheral blood mononuclear cells was significantly decreased due to $\mathrm{Cu}$ deficiency [71].

Copper has the persuasive capacity to reduce the effect of infectious viruses such as bronchitis virus, poliovirus, and human immunodeficiency virus type-1 (HIV-1). Copper shows its neutralizing effect on some enveloped and non-enveloped single and double-stranded DNA and RNA viruses. Peroxide and $\mathrm{Cu}$ ion mixture showed synergistic effect of killing viruses than glutaraldehyde in herpes simplex viruses (HSV) [72]. Exposure of human coronavirus 229E to copper regulates its genes, its DNA and also virus morphology, including dissolution of envelope and thinning out of surface spikes [73]. Evidence suggested that, the $\mathrm{n}-\mathrm{COV}$ showed high sensitivity on $\mathrm{Cu}$ surface and inactivated [74]. $\mathrm{Cu}^{2+}$ was shown to block papain-like protease-2, a protein that SARS-CoV-1 requires for replication in a cell-based study [75, 76].

\section{Lithium}

Lithium (Li) exhibits anti-viral effect against coronavirus bronchitis virus [73]. It inhibits replication and cellular entry of coronavirus in Vero cells and suppresses transcription, translation of viral proteins in a dose dependent manner [77]. Lithium possess anti-inflammmatory effects by inhibiting COX-2 expression, IL- $1 \beta$, TNF- $\alpha$ and increases the levels of IL-2, and IL-10. This activity of Li gives a clear figure to treat COVID-19 [78].

\section{Nickel}

Nickel (Ni) is an essential micronutrient, which is found in cells and tissues at reliable levels, and is also associated with DNA and RNA in suggested quantity of physiological significance. It is essential for modulation of immune system. Administration of low dose of nickel chloride causes immunotoxic effect [79]. Several studies have proven that $\mathrm{Ni}$ increases spleen $\mathrm{B}$ and $\mathrm{T}$ cell activities and decreases NK cells activities [79]. It has been observed that human coronavirus is rapidly inactivated at room temperature $\left(\sim 21^{\circ} \mathrm{C}\right)$ on alloy surfaces made up of copper and nickel, probably through generation of ROS [80] (Table 2). 
Table 2 Status of trace elements in various viral diseases along with their reference intervals in healthy adult individuals

\begin{tabular}{llll}
\hline S. no & Trace elements & Reference ranges of healthy adult individuals & Trends of trace elements in viral diseases \\
\hline 1 & Zinc & $66-110 \mu \mathrm{g} / \mathrm{dL}[85]$ & Decreased [39] \\
2 & Selenium & $5.8-23.4 \mu \mathrm{g} / \mathrm{dL}[85]$ & Decreased [51] \\
3 & Iron & $12.5-26 \mathrm{mmol} / \mathrm{L}[86]$ & Decreased [59] \\
4 & Copper & $75-145 \mu \mathrm{g} / \mathrm{dL} \mathrm{[85]}$ & Decreased [68] \\
5 & Lithium & $0.8-1.2 \mathrm{mmol} / \mathrm{L} \mathrm{[87]}$ & Decreased [78] \\
6 & Nickel & $0.3-1.1 \mu \mathrm{g} / \mathrm{L} \mathrm{[88]}$ & Decreased [80] \\
7 & Manganese & $4.7-18.3 \mu \mathrm{g} / \mathrm{dL} \mathrm{[85]}$ & Decreased [89] \\
8 & Chromium & $2-3 \mathrm{nmol} / \mathrm{L} \mathrm{[90]}$ & Decreased [91] \\
9 & Fluoride & $0.29-1.52 \mu \mathrm{mol} / \mathrm{L} \mathrm{[92]}$ & Decreased [93] \\
10 & Cobalt & $1.9-7.6 \mathrm{nmol} / \mathrm{L} \mathrm{[90]}$ & Decreased [94] \\
11 & Iodine & $40-80 \mu \mathrm{g} / \mathrm{L} \mathrm{[95]}$ & Mechanism unclear [96] \\
12 & Molybdenum & $0.28-1.17 \mathrm{ng} / \mathrm{mL}[97]$ & Decreased [98] \\
\hline
\end{tabular}

\section{Estimation of Trace Elements in Whole Blood/ Serum Samples}

The levels of trace elements can be estimated from serum/ whole blood samples of SARS-CoV-2 infected patients. The blood samples are collected by lithium heparin anticoagulant containing vacutainers. Inductively coupled plasma-mass spectrometry (ICP-MS) and inductively coupled plasma-optical emission spectrometry (ICP-OES) can be used for quantification of trace elements which are found in the $\mu \mathrm{g} / \mathrm{mL}$ or $\mathrm{ng} / \mathrm{mL}$ concentration ranges [81]. Other techniques includes ion selective electrodes (ISE), photometry, emission spectroscopy (ES), neutron activation analysis (NAA), anodic stripping voltammetry (ASV), atomic absorption spectrophotometry (AAS), high performance liquid chromatography (HPLC) and Total Reflection X-ray Fluorescence (TXRF) are used for quantification of trace elements. TXRF is a most proposed technique for quantification of trace elements. It is a cost effective, reliable method and can detect trace elements and their interactions in broad variety of biological samples. In testing body fluids, many sequential single element determination techniques are available. TXRF is a multi-trace element determination technique, time saving and requires minimal biological samples for analysis whereas, ICP-MS and ICP-OES are time consuming and requires lot of time for sample preparation. The main advantages of TXRF is picogram range of detection limit and more precise technique [82]. Trace element like copper levels can also be measured by functional tests, for example erythrocyte superoxide dismutase, serum ceruloplasmin and cytochrome c oxidase assays. Fluoride level is also measured by ion-specific potentiometry [83].

\section{Conclusions}

Trace elements are essential for activation, development, differentiation and perform numerous functions of immune cells. Molecular mechanisms of trace elements such as zinc, selenium and copper are fairly elucidated against SARS-CoV-2 infections [49, 84]. Few studies also available on the role of nickel and lithium in COVID-19 and other viral infections. Many experimental studies (both in vivo and in vitro) are ongoing to elucidate the molecular mechanisms of trace elements in anti-viral immunity of SARS-CoV-2. Minor trace elements have anti-viral activity on certain viruses such as influenza virus, HSV, HIV and BVDV viruses have been already demonstrated. Trace elements supporting the function and development of human immune system might reduce the risk of COVID19. All the above described nutritional importance of trace elements represents a healthy life style to be followed in normal time and quarantine period of COVID-19 infections. Intake of adequate sources of immune supportive micronutrients, proper time for eating along with positive approaches could be helpful for combating this COVID-19 pandemic situation.

\section{Future Perspectives}

Micronutrients have equal potential as like macronutrients with regards to development and maturation of immune system. Deficiency of micronutrients is one of the major public health concerns in the world. So far, based on the studies revealed trace elements have the immunomodulatory effects at various aspects. But still molecular mechanisms of many trace elements related to innate and acquired immunity are under reviled. 
Funding None.

\section{Compliance with Ethical Standards}

\section{Conflict of interest None.}

Ethical Clearance and Informed Consent Not applicable.

Open Access This article is licensed under a Creative Commons Attribution 4.0 International License, which permits use, sharing, adaptation, distribution and reproduction in any medium or format, as long as you give appropriate credit to the original author(s) and the source, provide a link to the Creative Commons licence, and indicate if changes were made. The images or other third party material in this article are included in the article's Creative Commons licence, unless indicated otherwise in a credit line to the material. If material is not included in the article's Creative Commons licence and your intended use is not permitted by statutory regulation or exceeds the permitted use, you will need to obtain permission directly from the copyright holder. To view a copy of this licence, visit http://creativecommons. org/licenses/by/4.0/.

\section{References}

1. Müller O, Neuhann F, Razum O. Epidemiology and control of COVID-19. Deutsche Medizinische Wochenschrift 1964. 2020;145(10):670-4.

2. Pandit K, Gupta S, Sharma AG. Clinico-pathogenesis of COVID19 in children. Indian $\mathrm{J}$ Biochem Biophys IJBB. 2020;57(3):264-9.

3. Moynihan AB, Van Tilburg WA, Igou ER, Wisman A, Donnelly AE, Mulcaire JB. Eaten up by boredom: consuming food to escape awareness of the bored self. Front Psychol. 2015;6:369.

4. Thurnham DI. Micronutrients and immune function: some recent developments. J Clin Pathol. 1997;50(11):887-91.

5. Razzaque M. COVID-19 pandemic: can maintaining optimal zinc balance enhance host resistance? Tohoku J Exp Med. 2020;251(3):175-81.

6. Chaturvedi UC, Shrivastava R, Upreti RK. Viral infections and trace elements: a complex interaction. Curr Sci. 2004;10:1536-54.

7. Gombart AF, Pierre A, Maggini S. A review of micronutrients and the immune system-working in harmony to reduce the risk of infection. Nutrients. 2020;12(1):236.

8. Pike J, Chandra RK. Effect of vitamin and trace element supplementation on immune indices in healthy elderly. Int J Vitam Nutr Res Internationale Zeitschrift fur Vitamin-und Ernahrungsforschung J Int de vitaminologieet de Nutr. 1995;65(2):117-21.

9. Nielsen FH. Manganese, molybdenum, boron, silicon, and other trace elements. Present Knowl Nutr. 2020;1:485.

10. Catanzaro M, Fagiani F, Racchi M, Corsini E, Govoni S, Lanni C. Immune response in COVID-19: addressing a pharmacological challenge by targeting pathways triggered by SARS-CoV-2. Signal Transduct Target Ther. 2020;5(1):1.

11. Miao L, Clair DK. Regulation of superoxide dismutase genes: implications in disease. Free Radic Biol Med. 2009;47(4):344-56.

12. Jarosz M, Olbert M, Wyszogrodzka G, Młyniec K, Librowski T. Antioxidant and anti-inflammatory effects of zinc. Zinc-dependent NF- $\mathrm{BB} \quad$ signaling. Inflammopharmacology. 2017;25(1):11-24.

13. Braciale TJ, Hahn YS. Immunity to viruses. Immunol Rev. 2013;255:5-12. https://doi.org/10.1111/imr.12109.
14. Li X, Geng M, Peng Y, Meng L, Lu S. Molecular immune pathogenesis and diagnosis of COVID-19. J Pharm Anal. 2020;10(2):102-8.

15. Prashanth L, Kattapagari KK, Chitturi RT, Baddam VR, Prasad LK. A review on role of essential trace elements in health and disease. J Dr NTR Univ Health Sci. 2015;4(2):75.

16. Bafaro E, Liu Y, Xu Y, Dempski RE. The emerging role of zinc transporters in cellular homeostasis and cancer. Signal Transduct Target Ther. 2017;2(1):1-2.

17. Feinauer CJ, Hofmann A, Goldt S, Liu L, Mate G, Heermann DW. Zinc finger proteins and the 3D organization of chromosomes. In: Advances in protein chemistry and structural biology. Academic Press; 2013. vol. 90, p. 67-117.

18. Wessels I, Maywald M, Rink L. Zinc as a gatekeeper of immune function. Nutrients. 2017;9(12):1286.

19. Molloy EJ, Aslam S, O'Hare F, Reen D. Immunology and immunodeficiencies. encyclopedia of paediatric surgery. Editor Prof PremPuri. Berlin: Springer; 2013. IBSN: 978-3-642-37878ER

20. Delgado-Roche L, Mesta F. Oxidative stress as key player in severe acute respiratory syndrome coronavirus (SARS-CoV) infection. Arch Med Res. 2020;51:384-7.

21. Ibs KH, Rink L. Zinc-altered immune function. J Nutr. 2003;133(5):S1452-6.

22. Schlesinger L, Arevalo M, Arredondo S, Lönnerdal B, Stekel A. Zinc supplementation impairs monocyte function. Acta Paediatr. 1993;82(9):734-8.

23. Fraker PJ, King LE, Garvy BA, Medina CA. The immunopathology of zinc deficiency in humans and rodents. In: Nutrition and immunology. Boston: Springer; 1993. p. 267-83.

24. Chandra RK, Dayton DH. Trace element regulation of immunity and infection. Nutr Res. 1982;2(6):721-33.

25. Read SA, Obeid S, Ahlenstiel C, Ahlenstiel G. The role of zinc in antiviral immunity. Adv Nutr. 2019;10(4):696-710.

26. Rahman MT, Idid SZ. Can Zn be a critical element in COVID-19 treatment? Biol Trace Elem Res. 2020;26:1-9.

27. Sawicki SG, Sawicki DL, Siddell SG. A contemporary view of coronavirus transcription. J Virol. 2007;81(1):20-9.

28. Denison MR, Zoltick PW, Hughes SA, Giangreco B, Olson AL, Perlman S, Leibowitz JL, Weiss SR. Intracellular processing of the N-terminal ORF 1a proteins of the coronavirus MHV-A59 requires multiple proteolytic events. Virology. 1992;189(1):274-84.

29. Suara RO, Crowe JE. Effect of zinc salts on respiratory syncytial virus replication. Antimicrob Agents Chemother. 2004;48(3):783-90.

30. Beck FW, Prasad AS, Kaplan J, Fitzgerald JT, Brewer GJ. Changes in cytokine production and $\mathrm{T}$ cell subpopulations in experimentally induced zinc-deficient humans. Am J Physiol Endocrinol Metabol. 1997;272(6):E1002-7.

31. Derwand R, Scholz M. Does zinc supplementation enhance the clinical efficacy of chloroquine/hydroxychloroquine to win todays battle against COVID-19? Med Hypotheses. 2020;6:109815.

32. Pal A, Pawar A, Goswami K, et al. Hydroxychloroquine and Covid-19: a cellular and molecular biology based update. Indian J Clin Biochem. 2020;35:274-84.

33. Sattar Y, Connerney M, Rauf H, Saini M, Ullah W, Mamtani S, Syed U, Luddington S, Walfish A. Three cases of COVID-19 disease with colonic manifestations. Am J Gastroenterol. 2020;115(6):948-50.

34. Pawar A, Pal A. Molecular and functional resemblance of dexamethasone and quercetin: a paradigm worth exploring in dexamethasone-nonresponsive COVID-19 patients. Phytother Res. 2020;34(12):3085-8. 
35. Hoffmann M, Kleine-Weber H, Krüger N, Mueller MA, Drosten C, Pöhlmann S. The novel coronavirus 2019 (2019-nCoV) uses the SARS-coronavirus receptor ACE2 and the cellular protease TMPRSS2 for entry into target cells. BioRxiv; 2020.

36. Zhang H, Penninger JM, Li Y, Zhong N, Slutsky AS. Angiotensin-converting enzyme 2 (ACE2) as a SARS-CoV-2 receptor: molecular mechanisms and potential therapeutic target. Intensive Care Med. 2020;46(4):586-90.

37. Speth R, Carrera E, Jean-Baptiste M, Joachim A, Linares A. Concentration-dependent effects of zinc on angiotensin-converting enzyme-2 activity (10674). FASEB J. 2014;28:1067-74.

38. Pal A, Squitti R, Picozza M, Pawar A, Rongioletti M, Dutta AK, Sahoo S, Goswami K, Sharma P, Prasad R. Zinc and COVID-19: basis of current clinical trials. Biol Trace Elem Res. 2020;22:1-1.

39. Chilvers MA, McKean M, Rutman A, Myint BS, Silverman M, O'Callaghan C. The effects of coronavirus on human nasal ciliated respiratory epithelium. Eur Respir J. 2001;18(6):965-70.

40. Wessels I, Rolles B, Rink L. The potential impact of zinc supplementation on COVID-19 pathogenesis. Front Immunol. 2020;11:1712.

41. Darma A, Ranuh RG, Merbawani W, Setyoningrum RA, Hidajat B, Hidayati SN, Endaryanto A, Sudarmo SM. Zinc supplementation effect on the bronchial cilia length, the number of cilia, and the number of intact bronchial cell in zinc deficiency rats. Indones Biomed J. 2020;12(1):78-84.

42. Wessels I, Pupke JT, von Trotha KT, Gombert A, Himmelsbach A, Fischer HJ, Jacobs MJ, Rink L, Grommes J. Zinc supplementation ameliorates lung injury by reducing neutrophil recruitment and activity. Thorax. 2020;75(3):253-61.

43. Huang Z, Rose AH, Hoffmann PR. The role of selenium in inflammation and immunity: from molecular mechanisms to therapeutic opportunities. Antioxid Redox Signal. 2012;16(7):705-43.

44. Hoffmann PR, Berry MJ. The influence of selenium on immune responses. Mol Nutr Food Res. 2008;52(11):1273-80.

45. Lee S, Kim SM, Lee RT. Thioredoxin and thioredoxin target proteins: from molecular mechanisms to functional significance. Antioxid Redox Signal. 2013;18(10):1165-207.

46. Girodon F, Galan P, Monget AL, Boutron-Ruault MC, BrunetLecomte P, Preziosi P, Arnaud J, Manuguerra JC, Hercberg S. Impact of trace elements and vitamin supplementation on immunity and infections in institutionalized elderly patients: a randomized controlled trial. Arch Intern Med. 1999;159(7):748-54.

47. Avery JC, Hoffmann PR. Selenium, selenoproteins, and immunity. Nutrients. 2018;10(9):1203.

48. Taheri M, Bahrami A, Habibi P, Nouri F. A review on the serum electrolytes and trace elements role in the pathophysiology of COVID-19. Biol Trace Elem Res. 2020;8:1-7.

49. Kieliszek M, Lipinski B. Selenium supplementation in the prevention of coronavirus infections (COVID-19). Med Hypotheses. 2020;143:109878.

50. Beck MA, Levander OA, Handy J. Selenium deficiency and viral infection. J Nutr. 2003;133(5):1463S-S1467.

51. Harthill M. Micronutrient selenium deficiency influences evolution of some viral infectious diseases. Biol Trace Elem Res. 2011;143(3):1325-36.

52. Brugliera L, Spina A, Castellazzi P, Cimino P, Arcuri P, Negro A, Houdayer E, Alemanno F, Giordani A, Mortini P, Iannaccone S. Nutritional management of COVID-19 patients in a rehabilitation unit. Eur J Clin Nutr. 2020;20:1-4.

53. Zhang J, Taylor EW, Bennett K, Saad R, Rayman MP. Association between regional selenium status and reported outcome of COVID-19 cases in China. Am J Clin Nutr. 2020;111(6):1297-9.
54. Zhang J, Li G, Liu X, Wang Z, Liu W, Ye X. Influenza A virus M1 blocks the classical complement pathway through interacting with C1qA. J Gen Virol. 2009;90(11):2751-8.

55. Pachetti M, Marini B, Benedetti F, Giudici F, Mauro E, Storici P, Masciovecchio C, Angeletti S, Ciccozzi M, Gallo RC, Zella D. Emerging SARS-CoV-2 mutation hot spots include a novel RNAdependent-RNA polymerase variant. J Transl Med. 2020;18:1-9.

56. Ma X, Bi S, Wang Y, Chi X, Hu S. Combined adjuvant effect of ginseng stem-leaf saponins and selenium on immune responses to a live bivalent vaccine of Newcastle disease virus and infectious bronchitis virus in chickens. Poult Sci. 2019;98(9):3548-56.

57. Liu C, Liang MC, Soong TW. Nitric oxide, iron and neurodegeneration. Front Neurosci. 2019;13:114.

58. Ruddell RG, Hoang-Le D, Barwood JM, Rutherford PS, Piva TJ, Watters DJ, Santambrogio P, Arosio P, Ramm GA. Ferritin functions as a proinflammatory cytokine via iron-independent protein kinase $\mathrm{C}$ zeta/nuclear factor kappaB-regulated signaling in rat hepatic stellate cells. Hepatology. 2009;49(3):887-900.

59. Mullick S, Rusia U, Sikka M, Faridi MA. Impact of iron deficiency anaemia on $\mathrm{T}$ lymphocytes and their subsets in children. Indian J Med Res. 2006;124(6):647-54.

60. Aly SS, Fayed HM, Ismail AM, Hakeem GL. Assessment of peripheral blood lymphocyte subsets in children with iron deficiency anemia. BMC Pediatr. 2018;18(1):49.

61. Attia MA, Essa SA, Nosair NA, Amin AM, El-Agamy OA. Effect of iron deficiency anemia and its treatment on cell mediated immunity. Indian J Hematol Blood Transfus. 2009;25(2):70-7.

62. Kuvibidila SR, Porretta C, Baliga BS, Leiva LE. Reduced thymocyte proliferation but not increased apoptosis as a possible cause of thymus atrophy in iron-deficient mice. $\mathrm{Br} \mathrm{J}$ Nutr. 2001;86(2):157-62.

63. Munoz C, Rios E, Olivos J, Brunser O, Olivares M. Iron, copper and immunocompetence. Br J Nutr. 2007;98(S1):S24-8.

64. Belouzard S, Millet JK, Licitra BN, Whittaker GR. Mechanisms of coronavirus cell entry mediated by the viral spike protein. Viruses. 2012;4(6):1011-33.

65. Liu W, Zhang S, Nekhai S, Liu S. Depriving iron supply to the virus represents a promising adjuvant therapeutic against viral survival. Curr Clin Microbiol Rep. 2020;20:1-7.

66. Chan JF, Lau SK, To KK, Cheng VC, Woo PC, Yuen KY. Middle East respiratory syndrome coronavirus: another zoonotic betacoronavirus causing SARS-like disease. Clin Microbiol Rev. 2015;28(2):465-522.

67. Stadler K, Masignani V, Eickmann M, Becker S, Abrignani S, Klenk HD, Rappuoli R. SARS—beginning to understand a new virus. Nat Rev Microbiol. 2003;1(3):209-18.

68. Koller LD, Mulhern SA, Frankel NC, Steven MG, Williams JR. Immune dysfunction in rats fed a diet deficient in copper. Am J Clin Nutr. 1987;45(5):997-1006.

69. Kelley DS, Daudu PA, Taylor PC, Mackey BE, Turnlund JR. Effects of low-copper diets on human immune response. Am J Clin Nutr. 1995;62(2):412-6.

70. Babu U, Failla ML. Respiratory burst and candidacidal activity of peritoneal macrophages are impaired in copper-deficient rats. J Nutr. 1990;120(12):1692-9.

71. Lukasewycz OA, Prohaska JR. The immune response in copper deficiency. Ann N Y Acad Sci. 1990;587:147-59.

72. Heresi G, Castillo-Durán C, Muñoz C, Arévalo M, Schlesinger L. Phagocytosis and immunoglobulin levels in hypocupremic infants. Nutr Res. 1985;5(12):1327-34.

73. Sagripanti JL, Routson LB, Lytle CD. Virus inactivation by copper or iron ions alone and in the presence of peroxide. Appl Environ Microbiol. 1993;59(12):4374-6.

74. Warnes SL, Little ZR, Keevil CW. Human coronavirus $229 \mathrm{E}$ remains infectious on common touch surface materials. MBio. 2015;6(6):e01697. 
75. Van Doremalen N, Bushmaker T, Morris DH, Holbrook MG, Gamble A, Williamson BN, Tamin A, Harcourt JL, Thornburg NJ, Gerber SI, Lloyd-Smith JO. Aerosol and surface stability of SARS-CoV-2 as compared with SARS-CoV-1. N Engl J Med. 2020;382(16):1564-7.

76. Han YS, Chang GG, Juo CG, Lee HJ, Yeh SH, Hsu JT, Chen X. Papain-like protease 2 (PLP2) from severe acute respiratory syndrome coronavirus (SARS-CoV): expression, purification, characterization, and inhibition. Biochemistry. 2005;44(30):10349-59.

77. Báez-Santos YM, John SE, Mesecar AD. The SARS-coronavirus papain-like protease: structure, function and inhibition by designed antiviral compounds. Antivir Res. 2015;115:21-38.

78. Harrison SM, Tarpey I, Rothwell L, Kaiser P, Hiscox JA. Lithium chloride inhibits the coronavirus infectious bronchitis virus in cell culture. Avian Pathol. 2007;36(2):109-14.

79. Gómez-Bernal G. Lithium for the 2019 novel coronavirus. Med Hypotheses. 2020;142:109822. https://doi.org/10.1016/j.mehy. 2020.109822.

80. Ilbäck NG, Benyamin G, Lindh U, Fohlman J, Friman G. Trace element changes in the pancreas during viral infection in mice. Pancreas. 2003;26(2):190-6.

81. Harrington JM, Young DJ, Essader AS, Sumner SJ, Levine KE. Analysis of human serum and whole blood for mineral content by ICP-MS and ICP-OES: development of a mineralomics method. Biol Trace Elem Res. 2014;160(1):132-42.

82. Cinosi A, Andriollo N, Pepponi G, Monticelli D. A novel total reflection X-ray fluorescence procedure for the direct determination of trace elements in petrochemical products. Anal Bioanal Chem. 2011;399(2):927-33.

83. Fuchs C, Dorn D, Fuchs CA, Henning HV, McIntosh C, Scheler F, Stennert M. Fluoride determination in plasma by ion selective electrodes: a simplified method for the clinical laboratory. Clin Chim Acta. 1975;60(2):157-67.

84. Kumar A, Kubota Y, Chernov M, Kasuya H. Potential role of zinc supplementation in prophylaxis and treatment of COVID-19. Med Hypotheses. 2020;25:109848.

85. Lee YH, Bang ES, Lee JH, Lee JD, Kang DR, Hong J, Lee JM. Serum concentrations of trace elements zinc, copper, selenium, and manganese in critically ill patients. Biol Trace Elem Res. 2019;188(2):316-25.

86. Penkova M, Ivanova N. Serum iron metabolism variables in clinically healthy persons. Open Access Macedonian J Med Sci. 2019;7(3):318.
87. Reddy DS, Reddy MS. Serum lithium levels: ideal time for sample collection! Are we doing it right? Indian J Psychol Med. 2014;36(3):346.

88. Templeton DM, Sunderman FW Jr, Herber RF. Tentative reference values for nickel concentrations in human serum, plasma, blood, and urine: evaluation according to the TRACY protocol. Sci Total Environ. 1994;148(2-3):243-51.

89. Beach RS, Gershwin ME, Hurley LS. Zinc, copper, and manganese in immune function and experimental oncogenesis. Nutr Cancer. 1981;3(3):172-91.

90. Burtis CA, Ashwood ER, Bruns DE. Tietz textbook of clinical chemistry and molecular diagnostics-e-book. Amsterdam: Elsevier Health Sciences; 2012.

91. Terpiłowska S, Siwicki AK. Chromium (III) and iron (III) inhibits replication of DNA and RNA viruses. Biometals. 2017;30(4):565-74.

92. Husdan HR, Vogl R, Oreopoulos D, Gryfe C, Rapoport A. Serum ionic fluoride: normal range and relationship to age and sex. Clin Chem. 1976;22(11):1884-8.

93. Prahoveanu E, Eşanu V. The effect of sodium fluoride on experimental influenza virus infection in mice. Virologie. 1981;32(4):293-5 (PMID: 7331235).

94. Vellema P, Rutten VP, Hoek A, Moll L, Wentink GH. The effect of cobalt supplementation on the immune response in vitamin B12 deficient Texel lambs. Vet Immunol Immunopathol. 1996;55(1-3):151-61.

95. Allain P, Berre S, Krari N, Laine-Cessac P, Le Bouil A, Barbot $\mathrm{N}$, Rohmer V, Bigorgne JC. Use of plasma iodine assay for diagnosing thyroid disorders. J Clin Pathol. 1993;46(5):453-5.

96. Bilal MY, Dambaeva S, Kwak-Kim J, Gilman-Sachs A, Beaman KD. A role for iodide and thyroglobulin in modulating the function of human immune cells. Front Immunol. 2017;8:1573.

97. Versieck J, Hoste J, Barbier F, Vanballenberghe L, De Rudder J, Cornelis R. Determination of molybdenum in human serum by neutron activation analysis. Clin Chim Acta. 1978;87(1):135-40.

98. Inouye Y, Tokutake Y, Yoshida T, Seto Y, Hujita H, Dan K, Yamamoto A, Nishiya S, Yamase T, Nakamura S. In vitro antiviral activity of polyoxomolybdates. Mechanism of inhibitory effect of PM-104 (NH4)12H2(Eu4(MoO4(H2O)16(Mo7O24)4)13H2O on human immunodeficiency virus type 1. Antivir Res. 1993;20(4):317-31.

Publisher's Note Springer Nature remains neutral with regard to jurisdictional claims in published maps and institutional affiliations. 